J. Lake Sci. (湖泊科学), 2014, 26(1): 121-130

http : //www. jlakes.org. E-mail : jlakes@niglas.ac.cn

(C) 2014 by Journal of Lake Sciences

\title{
黑河流域浮游植物群落特征与环境因子的关系”
}

\author{
郝媛媛 $^{1,2}$, 孙国钧 $^{1}$, 张立勋 $^{1 * *}$, 龚雪平 ${ }^{1}$, 许莎莎 ${ }^{1}$, 刘慧明 $^{1}$, 张 $^{\text {芬 }^{1}}$ \\ ( 1 : 兰州大学生命科学学院,兰州 730000) \\ (2: 兰州大学资源环境学院, 兰州 730000)
}

摘 要: 分别于 2009 年夏季和 2010 年夏、秋季对黑河流域进行了 2 次全面调查,共选取 76 个采样断面进行水样采集,鉴 定出浮游植物 242 种, 隶属于 8 门 11 纲 25 目 45 科 94 属. 其中硅藻门为优势类群, 占物种总数的 $38.43 \%$, 绿藻门和蓝藻 门次之; 黑河流域优势种为尺骨针杆藻 (Synedra ulna)、无常蓝纤维藻 (Dactylococcopsis irregularis) 和尖针杆藻 (S. acus), 优势度分别为 $0.060 、 0.031$ 和 0.021 , 出现频度分别为 $43.42 \% 、 43.42 \%$ 和 $46.05 \%$. 生物多样性指数及相关指数分析表 明, 黑河流域中、下游浮游植物群落结构的复杂程度和稳定性均高于上游; 同时, 综合生物多样性指数及相关指数以及水 质理化指标表明, 黑河上游水质为无污染或轻度污染, 中、下游水质为轻中度污染. 浮游植物丰度与环境因子的相关性分 析表明, 上游浮游植物丰度与水体硬度呈显著正相关; 中游浮游植物丰度则与各环境因子无显著相关性; 下游浮游植物 丰度与水体硬度呈显著负相关, 而与总氮 $\times$ 总磷呈显著正相关; 总溶解性固体、 $\mathrm{pH}$ 值和水体硬度与全流域浮游植物丰度 呈显著正相关. 黑河流域浮游植物的空间分布具有与河水水文分带相对应的垂直地带性和水平地带性分异特征.

关键词: 黑河流域;浮游植物; 群落特征;生物多样性;环境因子

\section{Relationship between community characteristics of the phytoplankton and environmental factors in Heihe River basin}

\section{HAO Yuanyuan ${ }^{1,2}$, SUN Guojun ${ }^{1}$, ZHANG Lixun ${ }^{1}$, GONG Xueping ${ }^{1}$, XU Shasha ${ }^{1}$, LIU Huiming ${ }^{1}$ \& ZHANG Fen ${ }^{1}$}

(1: School of Life Sciences, Lanzhou University, Lanzhou 730000, P. R. China)

(2: College of Earth and Environmental Sciences, Lanzhou University, Lanzhou 730000, P. R. China)

Abstract: Water samplings were collected at 76 sites across Heihe River basin during the comprehensive investigation in the summer of 2009 and summer and fall of 2010. 242 species, which belong to 8 divisions, 11 classes, 25 orders, 45 families and 94 genera, were identified from these water samplings. Bacillariophyta which makes up of $38.43 \%$ of the total number of the species is the dominant group, followed by Chlorophyta and Cyanophyta. Synedra ulna, Dactylococcopsis irregularis and S. acus are dominant species, whose ecological dominances are 0.060, 0.031 and 0.021. And frequencies of their occurrence are 43. 42\%, $43.42 \%$ and $46.05 \%$, respectively. The analysis of biodiversity indicates that the complex and stability of phytoplankton community in middle and downstreams are both higher than those of upstream. The water quality of upstream is of no-pollution or slightly polluted, but slightly or moderately polluted in the middle and downstream. The correlation analysis between basin-wide total phytoplankton abundance and environment factors of water shows that the phytoplankton abundance is positively correlated with water hardness in the upstream while the midstream phytoplankton abundance is not significantly related with any factors. In the downstream, the phytoplankton abundance is negatively correlated with water hardness but positively correlated with nutrient index of the total nitrogen multiply by the total phosphorus $(\mathrm{TN} \times \mathrm{TP})$. In the whole basin, phytoplankton abundance is positively correlated with total dissolved solids, $\mathrm{pH}$ and water hardness. The spatial distribution of phytoplankton in Heihe River basin shows obvious vertical zonality and horizontal zonality corresponding to differentiation characteristics of river hydrological zonation. These results

* 国家水体污染控制与治理科技重大专项项目(2008ZX07526-002-05)和国家自然科学基金项目(31101625)联合资 助. 2013-01-09 收稿;2013-04-08 收修改稿. 郝媛媛(1987 ), 女, 博士研究生; E-mail: haoyy10@ lzu. cn.

** 通信作者;E-mail: zhanglixun@lzu. edu. cn. 
showed the spatial correlationship between phytoplankton communities and their natural environment backgrounds. We hope this research could be favor to make policies to improve the management and sustainable utilization of the aquatic biological resources, to protect the water ecological environment in Heihe River basin and even other continental river basins.

Keywords: Heihe River basin; phytoplankton; community characteristics; biodiversity; environmental factors

浮游植物是水生态系统中最重要的初级生产者, 对维持水生态系统的平衡起着非常重要的作用, 其生 物量的多寡也直接影响水生态系统中其它水生生物的正常代谢 ${ }^{[1]}$ 以及水的理化性质 ${ }^{[2]}$, 同时, 水质的改变 也影响着浮游植物的个体、种群和群落 ${ }^{[3-6]}$. 因此, 浮游植物的群落结构特征是评价水环境质量的重要标 准 ${ }^{[7]}$, 因其能够反映水环境的污染状况 ${ }^{[8]}$ 且具有常规理化检测手段所欠缺的综合性、长期性及灵敏性等特 点 ${ }^{[9]}$, 而被广泛用于水质的生物学评价 ${ }^{[1]}$. 近年来我国学者利用浮游植物监测和评价水体污染状况的研究 多集中在长江 ${ }^{[10-13]}$ 、黄河 ${ }^{[14-15]}$ 、黑龙江 ${ }^{[16]}$ 等外流河及其支流流域, 对内陆河流域的研究较少, 仅有格尔木 河 ${ }^{[17]}$ 、塔里木河多浪水库 ${ }^{[18]}$ 和黑河流域部分河段和水库 ${ }^{[19-22]}$ 浮游植物的研究报道.

黑河流域是我国河西地区最大的内陆河流域, 是河西地区的重要水源之一. 近年来, 人类活动的加剧致 使黑河流域的生态环境急剧变化, 且不同程度地改变和正在改变着该河流径流量的季节分配, 与径流相关 的若干环境因子也发生了改变 ${ }^{[23-24]}$, 而环境因子的改变势必影响浮游生物群落的结构特征 ${ }^{[25-30]}$. 关于黑河 流域浮游植物的研究已有零星报道 ${ }^{[19-22]}$, 但多集中在 $1980 \mathrm{~s}$ 和 $1990 \mathrm{~s}$, 且研究区域均为中游, 对全流域浮游植 物的调查研究至今未见报道. 本研究通过对黑河流域浮游植物种类、密度、优势种及其优势度的研究, 探讨 了黑河全流域浮游植物的群落特征, 并分析了生物多样性在上、中、下游的形成机制, 同时利用生物多样性 指数从生物学角度对流域水质进行了评价, 此外, 运用相关性分析探讨了浮游植物丰度与水质理化指标之 间的关系, 以期为该流域水生生物资源的科学管理和可持续利用提供参考, 并为黑河流域乃至西北内陆河 流域水质评价及水体生态环境保护提供科学依据.

\section{1 研究区域及方法}

\section{1 研究区域概况及采样点设置}

黑河 $\left(37^{\circ} 45^{\prime} \sim 42^{\circ} 40^{\prime} \mathrm{N}, 96^{\circ} 42^{\prime} \sim 102^{\circ} 04^{\prime} \mathrm{E}\right.$ ) 是继塔里木河之后的我国第二大内陆河, 干流全长约 $821 \mathrm{~km}$, 流域面积 $12.8 \times 10^{4} \mathrm{~km}^{2[31]}$. 黑河发源于青藏高原东北缘的祁连山地, 从鹰落峡出祁连山, 人张掖绿洲, 经正 义峡流人内蒙古额济纳旗荒漠绿洲, 最终注人东、西居延海 ${ }^{[22]}$, 流经青海、甘肃和内蒙古三省 (自治区). 流 域地势南高北低、地形复杂, 自上而下可划分为祁连山地、河西走廊冲一洪积平原和阿拉善剥蚀高平原 ${ }^{[31]}$. 本研究样本采集分 2 次进行,2009 年 7-8 月对黑河全流域进行了系统而全面的调查,共布设采样点 45 个, 2010 年 7-10 月以重复验证为目的, 查缺补漏, 尽量使黑河的各个大小支流都有样点分布, 又布设采样点 49 个. 经过篮选和去重, 最终确定全流域研究样点 76 个 (图 1), 根据黑河的自然环境特征, 以鹰落峡和正义峡 为界将全流域分为上、中、下游三个区域, 其中上游 33 个 ( S1 S S3 ) 、中游 27 个 ( S34 S60)、下游 16 个 (S61 S76) 样点.

\section{2 研究方法}

1.2 .1 浮游植物定性分析 采用 $25^{\#}$ 浮游生物网, 根据实测截面水深, 选择中上层水位, 以“ $\infty$ ” 字型来回捞 取 $3 \mathrm{~min}$, 将取得的水样装人 $50 \mathrm{ml}$ 带盖采集管内, 捞取工作重复 3 次, 并加人 $3 \%$ 甲醛固定液 ( 按照水样: 固 定剂 $=4: 1$ ) 进行固定, 编号后带回实验室, 采用常规方法 ${ }^{[32]}$ 在显微镜下进行种类鉴定 ${ }^{[33-35]}$, 本文采用《中国 淡水藻类——系统、分类及生态》中的分类系统 ${ }^{[33]}$ 对所检浮游植物进行分类.

1.2 .2 浮游植物定量分析 使用水生生物采水器 ( $1 \mathrm{~L}$ ), 在水面上、中、下层分别采集水样, 混合后装人 $1.5 \mathrm{~L}$ 带盖采集瓶, 立即用鲁哥试剂进行固定 (每升水样加人 $15 \mathrm{ml}$ 鲁哥试剂), 统一编号, 带回实验室进行定量分 析研究. 采用直接计数法, 将加人鲁哥试剂的定量水样沉淀 $48 \mathrm{~h}$, 浓缩至约 $30 \mathrm{ml}$, 摇匀后迅速吸取 $0.1 \mathrm{ml}$ 浓 缩液置于 $0.1 \mathrm{ml}$ 浮游生物计数板内, 在 $10 \times 40$ 倍光学显微镜下按视野法进行计数, 每个样品做 5 个平行实 验并取其平均值 (每次计数结果与平均值之差应 $\leqslant 15 \%$, 否则重新计数), 最后计算出 $1 \mathrm{~L}$ 水样中浮游植物 的个体数 (即为丰度, 单位 cells/L). 


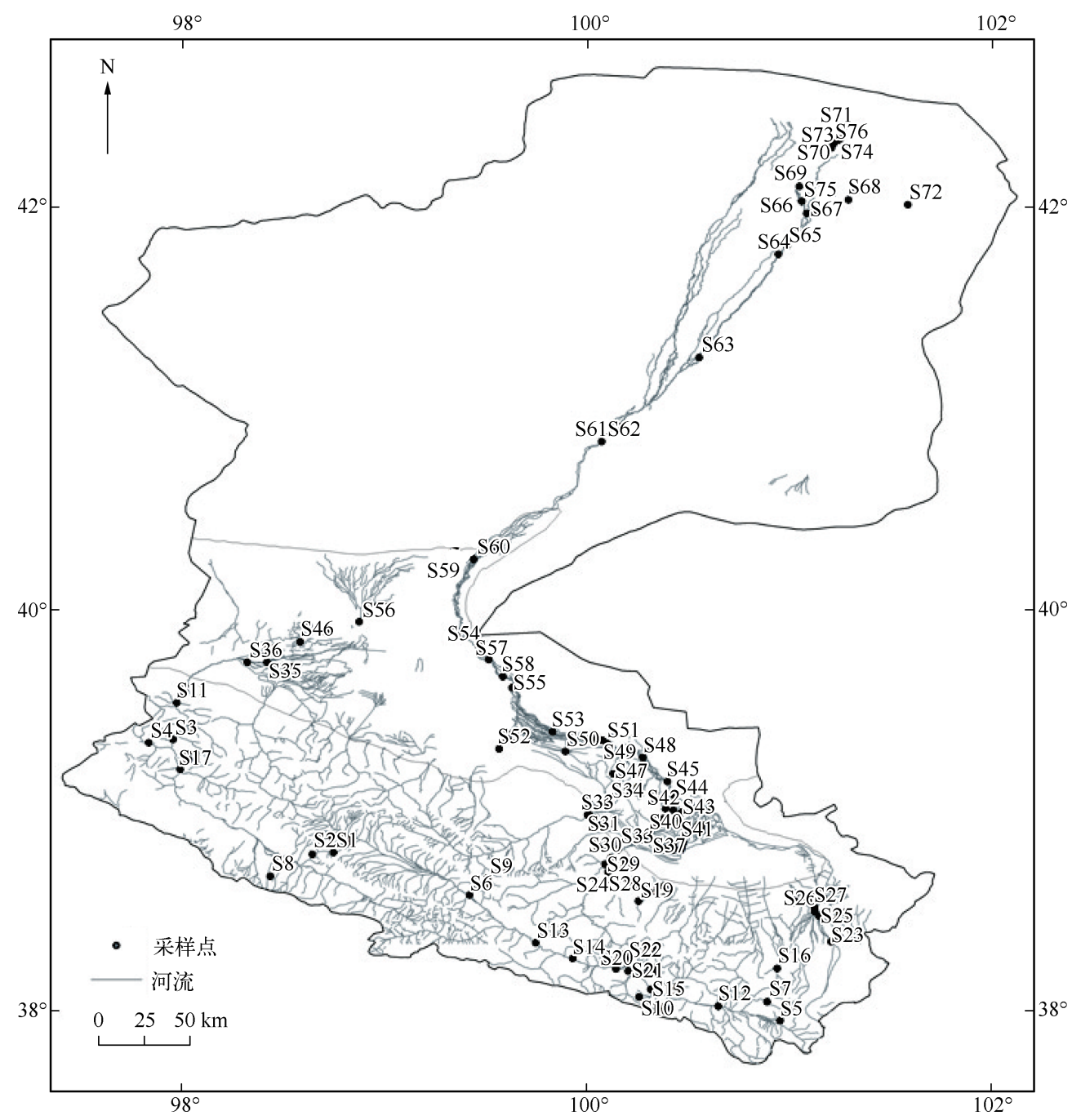

图 1 黑河流域浮游植物采样点分布

Fig. 1 The distribution of phytoplankton sampling sites in Heihe River basin

1.2 .3 水质水文分析 在采集浮游生物样品的同时, 在野外现场使用 GPS 测定各样点经纬度、海拔等地理指 标; 哈希便携式水质仪、浊度仪以及硬度试剂盒等仪器测定盐度、硬度、电导率、溶解氧、总溶解性固体、 $\mathrm{pH}$ 值、浊度等水质指标. 每个样点各取 $550 \mathrm{ml}$ 水样 2 瓶, 一瓶不加保存剂, 另一瓶加人 $2 \mathrm{ml}(1: 1)$ 硫酸, 编号后 于低温下保存运输, 于室内用重量法测定悬浮物、重铬酸钾滴定法测定化学需氧量、水杨酸分光光度法测定 氨氮、紫外分光光度法测定总氮、钼酸铵分光光度法测定总磷等其他水质指标 ${ }^{[36-37]}$.

\section{3 数据分析方法}

1.3 .1 优势度 优势种的优势度 $(Y)$ 计算公式 ${ }^{[38]}$ 为:

$$
Y=f_{i}\left(n_{i} / N\right)
$$

式中, $Y$ 为优势度, $n_{i}$ 为样品中第 $i$ 种浮游植物的个体数, $N$ 为样品中浮游植物总个体数, $f_{i}$ 为第 $i$ 种浮游植物 在各样点出现的频率, 当 $Y \geqslant 0.02$ 时的物种为优势种.

1.3 .2 生物多样性及其相关指数 生物多样性及其相关指数采用 Shannon-Wiener 多样性指数 ${ }^{[39]}(H) 、$ Pielou 
均匀度指数 ${ }^{[40]}(E) 、$ Simpson 优势度指数 ${ }^{[41]}\left(D_{s}\right)$, 计算公式分别为:

$$
\begin{gathered}
H=-\sum_{i=1}^{s} n_{i} \log _{2} n_{i} \\
E=H / \ln S \\
D_{s}=1-\sum_{i=1}^{s} n_{i}^{2}
\end{gathered}
$$

式中, $S$ 为浮游植物的种类数. $H$ 值在 $0 \sim 1.0$ 为重度污染, $1.0 \sim 3.0$ 为中度污染, $>3.0$ 为轻度污染或无污 染; $E$ 值在 $0 \sim 0.3$ 为重度污染, $0.3 \sim 0.5$ 为中度污染, $0.5 \sim 0.8$ 为轻度污染 ${ }^{[42]}$.

1.3 .3 数据处理 采用 SPSS 17.0 统计分析软件对所得数据进行处理, 得到浮游植物的优势度、ShannonWiener 多样性指数、Pielou 均匀度指数和 Simpson 优势度指数; 用 MATLAB 软件对浮游植物丰度与环境因子 进行相关性分析; 文中图表由 Origin 7.5 软件生成.

\section{2 结果}

\section{1 浮游植物群落结构}

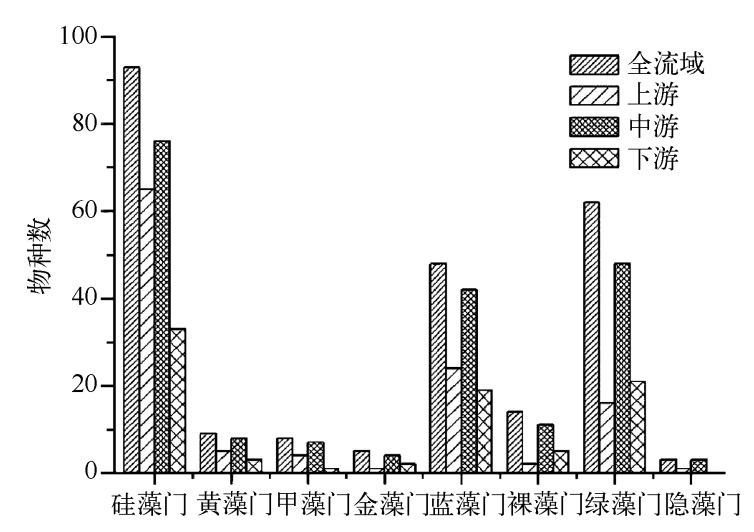

图 2 黑河全流域及上、中、下游浮游植物群落结构组成

Fig. 2 The community structure composition of phytoplankton in Heihe River basin of the whole, upper, middle and downstreams
2.1 .1 物种组成通过对所采 76 个水样进行镜 检和鉴定, 在黑河流域共鉴定出浮游植物 242 种(包括亚种、变种和变型), 隶属于 8 门 11 纲 25 目 45 科 94 属. 其中硅藻门最多, 有 93 种, 占 物种总数的 $38.43 \%$; 绿藻门次之, 有 62 种, 占 $25.62 \%$; 蓝藻门 48 种, 占 $19.83 \%$; 黄藻门、甲 藻门、裸藻门和金藻门分别有 9 种、8 种、14 种 和 5 种, 分别占 $3.72 \% 、 3.31 \% 、 5.79 \%$ 和 $2.07 \%$; 而隐藻门种数最少, 只有 3 种, 仅占物 种总数的 $1.23 \%$, 黑河流域浮游植物群落结构 见表 $1.83 .88 \%$ 的物种属于硅藻门、绿藻门和蓝 藻门 3 大类群. 上游 33 个样点共检出浮游植物 118 种, 中游 27 个样点检出浮游植物 199 种, 下 游 16 个样点检出 84 种浮游植物, 全流域及上、 中、下游各门的群落组成见图 2 .

2.1 .2 优势类群和优势种 各类群种类数目间 存在很大差异. 硅藻门的双壳缝目种类数占总

数的 $12.40 \%$, 为第一优势类群; 绿藻门的绿球藻目占 $11.57 \%$, 为第二优势类群; 蓝藻门的色球藻目占 $10.33 \%$, 为第三优势类群. 以上 3 大类群生物分布广泛, 对生境要求不高, 因而在物种竞争方面占优势, 利 于建群和生存, 因此易于成为优势类群.

根据公式 (1) 及 $Y \geqslant 0.02$ 的标准, 分别计算出上、中、下游以及全流域的优势种及其优势度. 上游优势种 有 2 种, 一种是尺骨针杆藻 (Synedra ulna), 优势度 0.034, 出现频度 $27.27 \%$, 另一种是尖针杆藻 ( S. acus), 优势度 0.021 , 出现频度 $33.33 \%$; 中游优势种有 4 种, 按优势度大小排列, 分别为尺骨针杆藻 $(0.075)$ 、尖针杆 藻 (0.034)、无常蓝纤维藻 (Dactylococcopsis irregularis, 0.030 ) 和膜孔平板藻 (Tabellaria fenestrata, 0.023), 出现 频度最小 $48.15 \%$, 最大 $62.96 \%$; 下游优势种有 3 种, 分别为尺骨针杆藻 $(0.085)$ 、无常蓝纤维藻 $(0.070)$ 和盘 氏鞘丝藻 (Lyngbya birgei, 0.048), 出现频度最小 $56.25 \%$, 最大 $87.50 \%$; 尺骨针杆藻 ( 0.060 )、无常蓝纤维藻 (0.031) 和尖针杆藻 $(0.021)$ 为全流域优势种, 出现频度分别为 $43.42 \% 、 43.42 \%$ 和 $46.05 \%$.

2.1 .3 丰度 本次调查发现全流域浮游植物平均丰度为 $2.01 \times 10^{5} \mathrm{cells} / \mathrm{L}$, 各样点丰度变化范围为 $0.40 \times$ $10^{4} \sim 5.83 \times 10^{5} \mathrm{cells} / \mathrm{L}$. 上、中、下游平均丰度分别为 $9.31 \times 10^{4} 、 2.42 \times 10^{5}$ 和 $3.56 \times 10^{5} \mathrm{cell} / \mathrm{L}$. 各门丰度占 总丰度的百分比如图 3 所示. 
表 1 黑河流域浮游植物群落结构

Tab. 1 Phytoplankton community structures in Heihe River basin

\begin{tabular}{|c|c|c|c|c|c|c|}
\hline 门 & 纲 & 目 & 科 & 属 & 种 & 所占百分比 \\
\hline \multirow[t]{3}{*}{ 蓝藻门 Cyanophyta } & \multirow[t]{3}{*}{ 蓝藻纲 Cyanophyceae } & 色球藻目 Chroococcales & 5 & 12 & 25 & $19.83 \%$ \\
\hline & & 颤藻目 Osillatoriales & 3 & 6 & 15 & \\
\hline & & 念珠藻目 Nostocales & 2 & 5 & 8 & \\
\hline 金藻门 Chrysophyta & 金藻纲 Chrysophyceae & 色金藻目 Chromulinales & 2 & 2 & 5 & $2.07 \%$ \\
\hline \multirow[t]{3}{*}{ 黄藻门 Xanthophyta } & \multirow[t]{2}{*}{ 黄藻纲 Xanthophyceae } & 柄球藻目 Mischococcales & 2 & 2 & 2 & $3.72 \%$ \\
\hline & & 黄丝藻目 Tribonematales & 1 & 1 & 6 & \\
\hline & 针胞藻纲 Raphidophyceae & 针胞藻目 Raphidales & 1 & 1 & 1 & \\
\hline \multirow{7}{*}{ 硅藻门 Bacillariophyta } & \multirow{5}{*}{ 羽纹纲 Pennatae } & 无壳缝目 Araphidiales & 1 & 5 & 19 & $38.43 \%$ \\
\hline & & 拟壳缝目 Raphidionales & 1 & 1 & 2 & \\
\hline & & 双壳缝目 Biraphidinales & 3 & 7 & 30 & \\
\hline & & 单壳缝目 Monoraphidales & 1 & 2 & 9 & \\
\hline & & 管壳缝目 Aulonoraphidinales & 3 & 5 & 17 & \\
\hline & \multirow[t]{2}{*}{ 中心纲 Centricae } & 圆篮藻目 Coscinodiscales & 1 & 2 & 15 & \\
\hline & & 根管藻目 Rhizosoleniales & 1 & 1 & 1 & \\
\hline 甲藻门 Dinophyta & 甲藻纲 Dinophyceae & 多甲藻目 Peridiniales & 1 & 1 & 8 & $3.31 \%$ \\
\hline 裸藻门 Euglenophyta & 裸藻纲 Euglenophyceae & 裸藻目 Euglenales & 1 & 6 & 14 & $5.79 \%$ \\
\hline \multirow[t]{8}{*}{ 绿藻门 Chlorophyta } & 双星藻纲 & 鼓藻目 Desmidiales & 1 & 8 & 20 & $25.62 \%$ \\
\hline & Zygnematophyceae & 双星藻目 Zygnematales & 1 & 2 & 2 & \\
\hline & \multirow[t]{6}{*}{ 绿藻纲 Chlorophyceae } & 团藻目 Volvocales & 2 & 5 & 7 & \\
\hline & & 绿球藻目 Chlorococcales & 7 & 14 & 28 & \\
\hline & & 四孢藻目 Tetrasporales & 1 & 1 & 1 & \\
\hline & & 石莼目 Ulvales & 1 & 1 & 1 & \\
\hline & & 胶毛藻目 Chaetophorales & 1 & 1 & 1 & \\
\hline & & 刚毛藻目 Cladophorales & 1 & 1 & 2 & \\
\hline 隐藻门 Cryptophyta & 隐藻纲 Cryptophyceae & 隐鞭藻目 Cryptomonadales & 1 & 2 & 3 & $1.23 \%$ \\
\hline 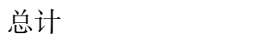 & 11 & 25 & 45 & 94 & 242 & $100 \%$ \\
\hline
\end{tabular}

\section{2 生物多样性及其水质评价}

黑河流域上、中、下游 Shannon-Wiener 指数分别为 $1.858 、 2.418 、 2.420$, Pielou 指 数分别为 $0.617 、 0.606 、 0.639$, Simpson 指数 分别为 $0.767 、 0.858 、 0.888$ (图 4). 结果表 明各样点间 Pielou 指数无明显变化 (介于 $0.341 \sim 0.680$ 之间), 样点间 Shannon-Wiener 指数和 Simpson 指数的变化趋势基本一 致. 黑河流域中、下游的 Shannon-Wiener 指 数和 Simpson 指数都高于上游, 说明中、下 游浮游植物群落结构的复杂程度和稳定性 均高于上游. 同时, Shannon-Wiener 指数分 析表明黑河各流域均属中度污染, 而 Simpson 指数则表明黑河各流域属轻度或无污 染. 结合所测水域水质理化指标 (表 2), 运 用模糊综合评价法对黑河流域水质进行分 析表明: 黑河流域上游水质状况良好, 中、下
表 2 黑河流域水质理化指标*

Tab. 2 The physico-chemical indicators of water quality in Heihe River basin

\begin{tabular}{lcccc}
\hline 理化指标 & 全流域 & 上游 & 中游 & 下游 \\
\hline 水温 $/{ }^{\circ} \mathrm{C}$ & 17.1 & 16.2 & 21.0 & 22.4 \\
氨氮 $/(\mathrm{mg} / \mathrm{L})$ & 0.344 & 0.296 & 0.562 & 0.077 \\
溶解氧 $/(\mathrm{mg} / \mathrm{L})$ & 5.95 & 5.58 & 6.34 & 6.07 \\
总溶解性固体 $/(\mathrm{mg} / \mathrm{L})$ & 535 & 307 & 399 & 1237 \\
$\mathrm{pH}$ & 7.59 & 7.35 & 7.59 & 8.10 \\
电导率 $/(\mu \mathrm{S} / \mathrm{cm})$ & 861 & 575 & 758 & 1623 \\
悬浮物 $/(\mathrm{mg} / \mathrm{L})$ & 88 & 78 & 65 & 148 \\
化学需氧量 $/(\mathrm{mg} / \mathrm{L})$ & 3.87 & 3.88 & 3.61 & 4.27 \\
总氮 $\times$ 总磷 & 0.238 & 0.137 & 0.353 & 0.250 \\
硬度 $/(\mathrm{mg} / \mathrm{L})$ & 565 & 440 & 569 & 815 \\
盐度 $/ \% 0$ & 0.549 & 0.321 & 0.393 & 1.281 \\
浊度 $/ \mathrm{NTU}$ & 109 & 86 & 78 & 208 \\
流速 $/(\mathrm{m} / \mathrm{s})$ & 0.934 & 1.27 & 0.673 & 0.674 \\
\hline
\end{tabular}

* 表中数据均为各区域平均值. 
游存在轻度污染, 且中游污染比下游严重 ${ }^{[43]}$. 综合考虑, 黑河流域上游水质为无污染或轻度污染, 中、下游水 质为轻中度污染.

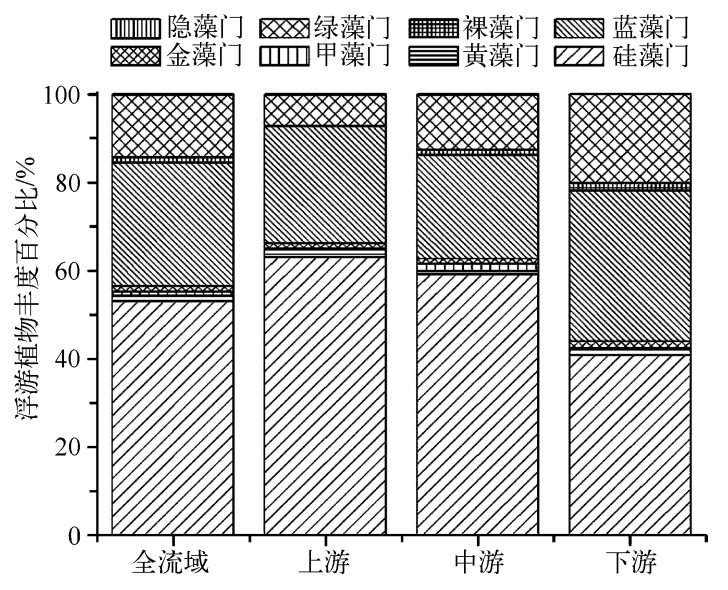

图 3 浮游植物各门丰度占 总丰度的百分比

Fig. 3 The percentage of each phylum abundance in the total abundance of phytoplankton

表 3 黑河流域各样点浮游植物丰度与环境因子的相关性

Tab. 3 Correlation between phytoplankton abundance of each site and environmental factors in Heihe River basin

\begin{tabular}{lrrrr}
\hline 相关因子 & 全流域 & \multicolumn{1}{c}{ 上游 } & \multicolumn{1}{c}{ 中游 } & \multicolumn{1}{c}{ 下游 } \\
\hline $\mathrm{BD}$ & 1.000 & 1.000 & 1.000 & 1.000 \\
$\mathrm{~T}$ & -0.122 & 0.029 & -0.346 & 0.236 \\
$\mathrm{NH}_{3}-\mathrm{N}$ & 0.003 & -0.183 & 0.117 & -0.053 \\
$\mathrm{DO}$ & 0.051 & -0.080 & -0.155 & 0.286 \\
$\mathrm{TDS}$ & $0.236^{*}$ & 0.313 & 0.037 & -0.126 \\
$\mathrm{pH}$ & $0.248^{*}$ & -0.113 & 0.361 & -0.267 \\
$\lambda$ & 0.194 & 0.301 & 0.043 & -0.105 \\
$\mathrm{SS}$ & -0.019 & -0.106 & -0.209 & 0.076 \\
$\mathrm{COD}$ & 0.021 & -0.090 & 0.091 & -0.131 \\
$\mathrm{TN} \times \mathrm{TP}$ & 0.010 & -0.031 & -0.169 & $0.502^{*}$ \\
$\mathrm{Ha}$ & $0.232^{*}$ & $0.382^{*}$ & 0.254 & $-0.474^{*}$ \\
$\mathrm{~S}$ & 0.222 & 0.168 & 0.014 & -0.124 \\
$\mathrm{Tur}$ & 0.074 & -0.127 & -0.365 & 0.413 \\
\hline
\end{tabular}

* 表示显著相关 $(P<0.05)$.

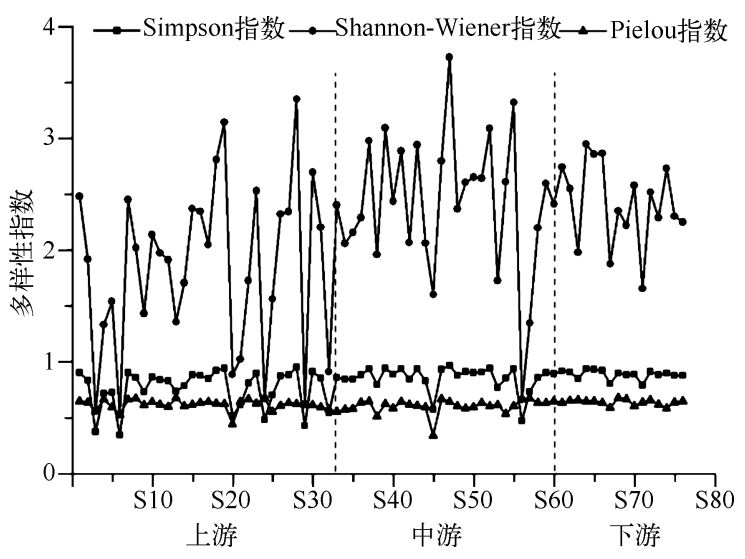

图 4 各样点浮游植物 Simpson 指数、 Shannon-Wiener 指数和 Pielou 指数 Fig. 4 Simpson index, Shannon-Wiener index and Pielou index of phytoplankton at each sampling site

\section{3 浮游植物群落与环境因子的关系}

浮游植物与环境有着密切的关系, 对各 样点浮游植物丰度 $(\mathrm{BD})$ 分别与水温 $(\mathrm{T})$ 、 氨氮 $\left(\mathrm{NH}_{3}-\mathrm{N}\right)$ 、溶解氧 $(\mathrm{DO})$ 、总溶解性固体 ( TDS)、 $\mathrm{pH}$ 值、电导率 $(\lambda)$ 、悬浮物 $(\mathrm{SS})$ 、化 学需氧量 $\left(\mathrm{COD}_{\mathrm{Mn}}\right)$ 、总氮 $\times$ 总磷 $(\mathrm{TN} \times \mathrm{TP})$ 、 硬度 $(\mathrm{Ha})$ 、盐度 $(\mathrm{S})$ 和浊度 $(\mathrm{Tur})$ 等 12 个因 子作相关性分析 (表 3), 结果表明: 黑河流 域上游各样点浮游植物丰度与水体硬度呈 显著正相关 $(P<0.05)$; 中游各样点浮游植 物丰度则与各环境因子无显著相关性; 下游 各样点浮游植物丰度与水体硬度呈显著负 相关 $(P<0.05)$, 而与营养盐指数 (总氮 $\times$ 总磷) 呈显著正相关 $(P<0.05)$; 总溶解性 固体、 $\mathrm{pH}$ 值和水体硬度与全流域各样点浮 游植物丰度呈显著正相关 $(P<0.05)$.

\section{3 讨论}

\section{1 黑河流域浮游植物的时空变化}

有文献记载 1990s 未期黑河流域的浮游植物为 109 种 ${ }^{[22]}$. 本研究在黑河流域共调查出 242 种浮游植 物, 种类远多于史料数据, 主要原因是本次研究涉及黑河干流及其各个大小支流, 且研究区域的经纬度跨度 分别为 $3.76^{\circ}$ 和 $4.39^{\circ}$, 海拔跨度达 $2947.8 \mathrm{~m}$, 采样点多达 76 个, 调查范围更广泛, 能更真实准确地反映黑河 流域浮游植物的种类现状.

黑河流域各河段浮游植物的种类和丰度都存在明显的空间差异性. 黑河流域上游浮游植物 118 种、中 
游 199 种、下游 84 种, 每个样点平均为 11 种. 硅藻 是广布种, 整个流域均有发现; 甲藻除上游个别样 点有分布外, 多数分布在中、下游, 这可反映出中、 下游流域与上游流域的水环境差异; 黄藻和金藻 仅存在于个别样点, 对比所测水样浊度, 符合其喜 光照、多存在于清洁水体的规律 ${ }^{[34]}$. 从整体看, 上、 中、下游样点的浮游植物平均丰度表现为: 上游 $\left(9.31 \times 10^{4}\right.$ cells $\left./ \mathrm{L}\right)<$ 中游 $\left(2.42 \times 10^{5}\right.$ cells $\left./ \mathrm{L}\right)<$ 下游 $\left(3.56 \times 10^{5} \mathrm{cells} / \mathrm{L}\right)$, 中、下游浮游植物平均丰 度明显多于上游, 分别是上游的 2.6 倍和 3.8 倍. 从极地到热带地区、从山地到低地, 动植物物种丰 富度的增加构成了地球上 2 个最显著的生物多样 性分布格局 ${ }^{[44]}$. 生物学家对近几个世纪大尺度范 围下大型有机体生物多样性的分布格局已研究的 相当透彻 ${ }^{[4547]}$, 但关于淡水浮游植物多样性在大 尺度下的生物地理学分布在很大程度上仍处于未 知状态. 仅 Stomp 等通过对美国陆地 540 个湖泊和 水库中淡水浮游植物多样性分布的研究, 发现纬 度、经度和海拔对浮游植物生物多样性有很大影 响, 因而可以证明淡水浮游植物的生物多样性同 样是随着地理变化而变化的, 而这种变化程度主 要取决于当地的环境因子 ${ }^{[48]}$. 浮游植物丰度与海 拔线性回归分析 (图 5A) 表明, 二者呈极显著负相 关性 $\left(R^{2}=0.34, P<0.01\right)$, 随着海拔的降低, 样点 浮游植物丰度呈显著增加趋势, 这与 Stomp 等的研 究结果相吻合 ${ }^{[48]}$. 同时也可以从另一方面验证黑 河流域浮游植物的空间分布具有与河水水文分带 相对应的垂直地理分异 ${ }^{[20]}$; 这也与李鹏等早期对 黑河流域的研究相符 ${ }^{[22]}$. 同样, 浮游植物丰度与 经、纬度均呈极显著正相关 $\left(R_{\text {经度 }}^{2}=0.36, R_{\text {纬度 }}^{2}=\right.$ $0.24, P<0.01)$, 即随着经、纬度的增加, 浮游植物 丰度增大 (图 5B、C), 说明黑河流域浮游植物的空 间分布还具有与河水水文分带相对应的水平地带 分异.

\section{2 黑河流域浮游植物与水质理化指标的相关性 分析}

水体硬度是影响上游 (显著正相关)、下游 (显 著负相关) 以及全流域 (显著正相关) 浮游植物丰 度的主要水质理化因子, 中游浮游植物丰度与各 水质理化因子无显著相关性(表 3 ). 主要原因是由
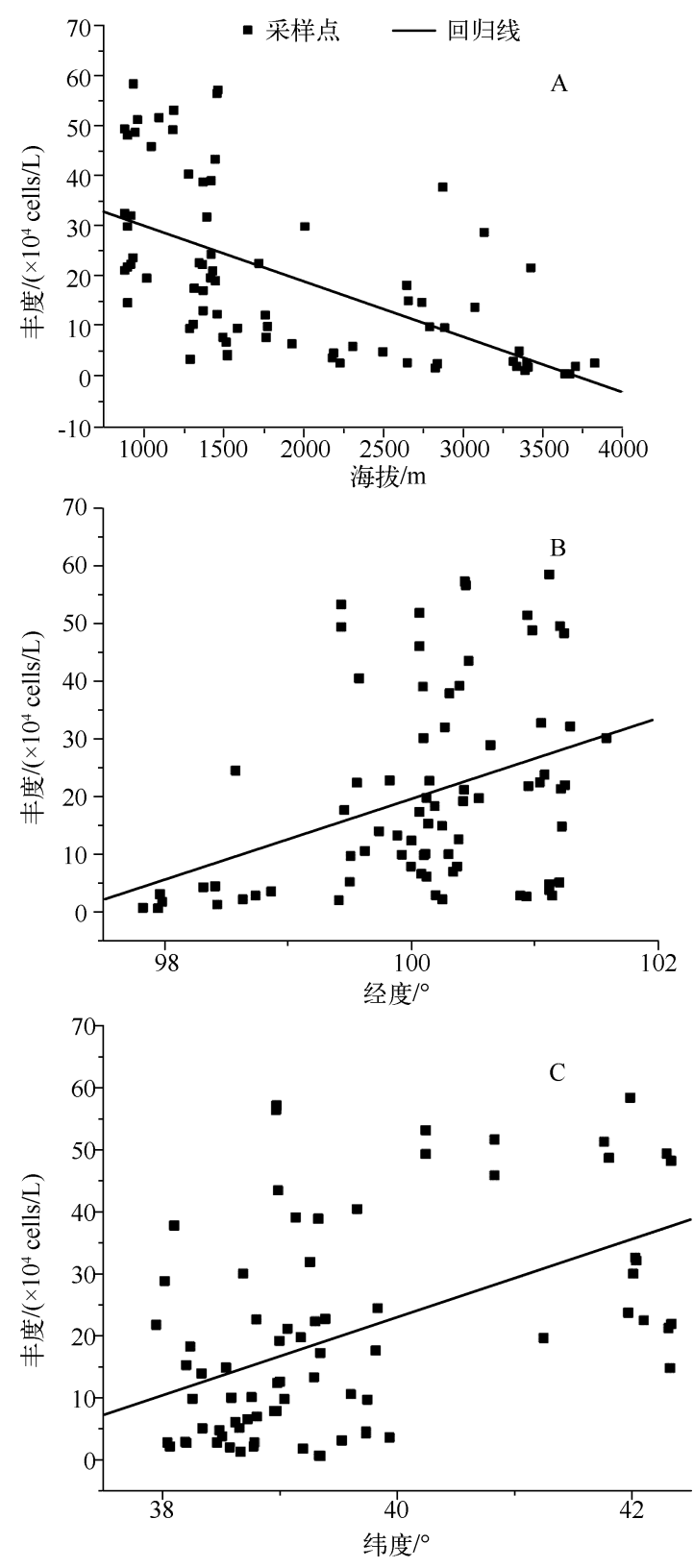

图 5 各样点浮游植物丰度 与海拔和经纬度的关系

Fig. 5 The relationships between phytoplankton abundance and elevation, longitude and latitude of each sampling site 于上游地处青藏高原东北部的祁连山区, 海拔在 $1700 \mathrm{~m}$ 以上, 平均海拔 $2783 \mathrm{~m}$, 气温较低, 加之祁连雪山融 水注人, 使得上游河水年积温小; 另一方面, 上游河床比降大, 水流速度快, 水温 ${ }^{[25,47,49]}$ 和水流 ${ }^{[26,50]}$ 对浮游植 物生存和繁殖有很大影响, 只适于狭冷型和流水型物种的生存, 因而物种数较少, 丰度较低; 在水温较低(年 均温不足 $2^{\circ} \mathrm{C}$ )、水流湍急的上游, 砾石和砂石底质的河床使得水体硬度 ${ }^{[51]}$ 成为限制上游狭冷型和流水型浮 
游植物生长最重要的水质因子. 中、下游位于海拔 $800 \sim 1600 \mathrm{~m}$ 的河西走廊平原和阿拉善剥蚀高平原, 海拔 较低, 气温较高, 适于大多数普生性种类的生长. 中游张掖绿洲由于工业和生活污水的注人, 水体有机质含 量增加, 丰富的营养盐含量 ${ }^{[12,30,52]}$ 使普生性浮游植物大量繁殖, 因而中游物种数多、丰度高; 下游阿拉善高 原由于气温高、蒸发量远远大于降水量, 致使水体矿化度较高, 因而半咸水种类居多, 水体硬度过小反而不 利于浮游植物的生长 ${ }^{[51]}$, 所以矿化度即总溶解性固体 ${ }^{[53]}$ 是影响下游浮游植物生存和分布的重要水质因子; 此外, 2000 年起国家实施的黑河干流统一调水工程加速了中游水量的下泄, 成功将中游水引人下游的额济 纳旗以及东、西居延海 ${ }^{[54]}$, 致使中下游水质状况相似也是导致中下游浮游植物物种数较多、丰度高的另一个 主要原因.

\section{3 黑河流域浮游植物优势类群和多样性评价}

黑河流域浮游植物优势类群以硅藻门和绿藻门为主, 这与长江 ${ }^{[12]}$ 、湘江 $^{[13]}$ 、黄河 ${ }^{[14-15]}$ 、黑龙江 ${ }^{[16]}$ 、格尔 木河 ${ }^{[17]}$ 、塔里木河 ${ }^{[18]}$ 等很多河流的研究结果相一致. 尽管造成浮游植物物种分布的因素各不相同, 但主要 还是取决于当地的环境因子 ${ }^{[47]}$. 由于黑河属于冰川融化形成的内陆水系, 水温较低, 很多狭温嗜暖性种类难 以滋生 ${ }^{[55]}$; 其次可能是因为硅藻门属于比较原始的门类, 而硅藻门和绿藻门多为狭冷性物种, 适合生活在较 冷的环境中 ${ }^{[56]}$; 绿藻适应性强, 无论是有机质丰富的水体 (如小球藻属 Chlorella、纤维藻属 Ankistrodesmus 等) 还是清洁水体 (如新月藻属Closterium、盘星藻属 Pediastrum、团藻属 Volvox 等) 中都能大量生长 ${ }^{[33]}$.

生物多样性是衡量一个区域生物资源丰富程度的一个客观指标, 学者们往往根据研究需要用不同的多 样性指数来解释和评价浮游植物群落结构特征 ${ }^{[42,57-58]}$. 本文采用能够反映浮游植物种群结构复杂程度、分散 程度以及种间个体分布均匀程度的 Shannon-Wiener 多样性指数、Simpson 优势度指数和 Pielou 均匀度指数对 黑河流域浮游植物群落结构多样性进行评价. 上游 $\left(H=1.86, E=0.62, D_{s}=0.77\right)$ 多样性指数较低, 群落结 构较简单, 物种分配较均匀, 种群分布较集中, 对外部环境变化和内部种群波动抵抗能力弱, 群落结构很不 稳定; 中游 $\left(H=2.42, E=0.61, D_{s}=0.86\right)$ 多样性指数较高, 群落结构相对复杂, 物种分配较均匀, 种群分布 相对分散, 对外部环境变化和内部种群波动抵抗能力较强, 群落结构相对稳定; 下游 $(H=2.42, E=0.64$, $\left.D_{s}=0.89\right)$ 多样性指数较高, 群落结构相对复杂, 物种分配较均匀, 种群分散程度大, 对外部环境变化和内部 种群波动抵抗能力强, 群落结构稳定. 根据 Shannon-Wiener 指数和 Pielou 指数对水质的评价标准 ${ }^{[59]}$, 上、中、 下游均为 $\beta$-中污型 $\rightarrow$ 清洁-寡污型水体, 结合黑河流域水域理化指标模糊评价法的评价结果 ${ }^{[43]}$, 综合考虑, 黑河上游水质为无污染或轻度污染, 中、下游水质为轻中度污染.

黑河复杂的环境条件是造成黑河流域上、中、下游浮游植物群落多样性呈三级台阶状递增的主要原因. 黑河属于冰川融水形成的内陆河水系, 从发源区祁连山麓到尾问湖泊居延海, 依次穿越了高山冰雪冻土带、 山区植被带、绿洲带、下游荒漠带四个气候带, 形成黑河特有的冰雪带一山地森林草原一山前绿洲一荒漠复合 生态系统 ${ }^{[31]}$. 另外, 黑河地表水和地下水的多次转化和重复利用 ${ }^{[60-61]}$ 以及人类活动引起的环境变化 ${ }^{[62]}$ 也影 响着浮游植物群落多样性. 黑河上游祁连山区海拔较高, 受人类活动影响较小; 中游河西走廊平原随着工、 农业的快速发展, 致使中游工业、农业及生活污水的直接或间接排人量增加, 不仅污染了黑河中游水质 ${ }^{[63]}$, 而且对黑河上游水质也造成了一定程度的污染 ${ }^{[64]}$, 还影响了下游阿拉善高原的水质以及生态环境保护. 因 此黑河流域水环境治理与保护刻不容缓.

黑河流域水环境的治理以及水生态建设与保护是国家“十一五”科技重大专项水体污染控制与治理的 重要内容, 事关流域内居民的生存环境和经济发展, 也关系到全流域的生态环境问题. 本文仅从浮游植物的 群落特征方面来反映黑河流域的生态特征, 以期为整个黑河流域的水环境治理及其生态保护提供可靠的理 论依据,为黑河流域水生态功能分区的研究打好基础.

致谢: 感谢金宝成等帮助采样以及在本文写作过程中提供的指导与帮助!

\section{4 参考文献}

[1] 郭春燕, 冯 佳, 谢树莲. 山西晋阳湖浮游藻类分布的时空格局及水质分析. 湖泊科学, 2010,22(2):251-255.

[2] 刘冬燕, 赵建夫, 张亚雷等. 富营养水体生物修复中浮游植物的群落特征. 水生生物学报, 2005,29(2):177-183.

[ 3 ] 沈会涛, 刘存歧. 白洋淀浮游植物群落及其与环境因子的典范对应分析. 湖泊科学, 2008,20(1):773-779. 
[ 4 ] Lepistö L, Holopainen AL, Vuoristo H. Type-specific and indicator taxa of phytoplankton as a quality criterion for assessing the ecological status of Finnish boreal lakes. Limnologica-Ecology and Management of Inland Waters, 2004,34 (3) : $236-248$.

[ 5] 吴 波, 陈德辉, 徐英洪等. 苏州河浮游植物群落结构及其对水环境的指示作用. 上海师范大学学报: 自然科学版, 2006,35 ( 5 ) :64-70.

[6] 朱 英, 沈根祥, 钱晓雍等. 上海大莲湖水域浮游植物群落结构特征及水质评价. 生态与农村环境学报, 2010,26 (6) :544-549.

[ 7 ] 韩欢欢, 范亚文. 黑龙江省安兴湿地秋季浮游植物群落结构. 湖泊科学, 2012,24(4):577-585.

[ 8 ] Suikkanen S, Laamanen M, Huttunen M. Long-term changes in summer phytoplankton communities of the open northernBaltic Sea. Estuarine, Coastal and Shelf Science, 2007, 71(3/4) : 580-592.

[ 9 ] 杨培莎,朱艳华. 水质生物监测方法及应用展望. 北方环境,2010,22(2):71-73.

[10] 奕青杉, 孙 军. 2005 年夏季长江口水域浮游植物群集特征及其与环境因子的关系. 生态学报, 2010,30 (18): $4967-4975$.

[11] 任丽平,马永红. 嘉陵江浮游生物群落结构研究. 天然产物研究与开发, 2012,24:1129-1134,1150.

[12] 李世建, 范振华, 任玉芹等. 长江中游宜昌至城陵矶江段浮游植物群落结构的周年变化特征. 长江流域资源与环 境, 2012,21 ( Z1 ):62-68.

[13] 张 校, 肖 玲, 刘应迪等. 湘江长沙段浮游植物区系组成及水质评价初步研究. 湖南师范大学: 自然科学学报, 2012,35 (4):74-79.

[14] 王晓臣, 杨兴中, 吕涁涁等. 黄河下游浮游植物群落结构及其与环境因子的关系. 安徽农业科技,2012, 40 (18): 9819-9821.

[15] 王 勇, 王海军, 赵伟华等. 黄河干流浮游植物群落特征及其对水质的指示作用. 湖泊科学, 2010,22(5):700-707.

[16] 李 萿, 姜作发, 霍堂斌等. 黑龙江中游浮游植物多样性动态变化及水质评价. 中国水产科学, 2012, 19(4): $671-678$.

[17] 陈燕琴, 申志新, 刘玉婷. 柴达木水系格尔木河秋季浮游植物群落结构特征初步研究. 青海农林科技,2012,(2): $10-15,60$.

[18] 陈生謷,王 帅, 周 刚等. 塔里木河流域多浪水库浮游生物的调查研究. 塔里木大学学报,2011,23(3):30-36.

[19］渔业资源调查与区划研究课题组. 甘肃内陆河流域渔业资源调查. 甘肃农业科技,1985, 甘肃渔业资源专辑:65-69.

[20] 赵铁桥,王基琳. 河西内陆水系的水生生物调查. 高原生物学集刊,1984,2:45-51.

[21] 李 鹏, 钟琼芳. 张掖人工池塘浮游植物群落研究. 西北植物学报, 1994,14(6):127-133.

[22] 李 鹏, 安黎哲, 冯虎元等. 黑河流域浮游植物及其地理分布特征研究. 西北植物学报,2001,21(5):966-972.

[23] Mahoney R, Tucker CJ, Anyamba Y et al. Global remote sensing of vegetation from space by the NASA/GSFC GIMMS Group in International Workshop on Global Change. Tohoku University: Sendai Kiodo Printing Co. Ltd, 2001.

[24] Chen J, Jönsson P, Tamura M et al. A simple method for reconstructing a high-quality NDVI time-series data set based on the Savitzky-Golay filter. Remote Sensing of Environment, 2004, 91 (3/4) : 332-344.

[25] Reynolds CS, Huszar V, Kruk C et al. Towards a functional classification of the freshwater phytoplankton. Journal of Plankton Research, 2002, 24(5) : 417-428.

[26] Burford MA, Johnson SA, Cook AJ et al. Correlations between watershed and reservoir characteristics, and algal blooms in subtropical reservoirs. Water Research, 2007, 41(18) : 4105-4114.

[27] 钟 瑜, 黄良民, 黄小平等. 冬夏季雷州半岛附近海域微微型光合浮游生物的类群变化及环境影响. 生态学报, 2009,29 (6):3000-3008.

[28] 许木启, 朱 江, 曹 宏. 白洋淀原生动物群落多样性变化与水质关系研究. 生态学报,2001,21(7):1114-1120.

[29] 欧阳吴, 韩博平. 从东江调水后契爷石水库的水质和浮游植物群落结构特征. 湖泊科学, 2007,19(2):204-211.

[30] Nakane T, Nakaka K, Bouman H et al. Environmental control of short-term variation in the plankton community of inner Tokyo Bay, Japan. Estuarine, Coastal and Shelf Science, 2008, 78(4) : 796-810.

[31] 陈国栋. 黑河流域水一生态一经济系统综合管理研究. 北京:科学出版社,2009.

[32] 章宗涉, 黄祥飞. 淡水浮游生物研究方法. 北京: 科学出版社, 1991 .

[33] 胡鸿钧, 魏印心. 中国淡水藻类——系统、分类及生态. 北京: 科学出版社, 2006 .

[34] 胡鸿钧, 李尧英, 魏印心等. 中国淡水藻类. 上海: 上海科学技术出版社, 1980 . 
[35］韩茂森. 淡水浮游生物图谱. 北京:农业出版社, 1980.

[36] 奚旦立,孙裕生,刘秀英. 环境检测. 北京: 高等教育出版社, 1995.

[37] 国家环境保护总局《水和废水监测分析方法》编委会. 水和废水监测分析方法: 第 3 版. 北京: 中国环境科学出版 社,1989.

[38] 陈小庆,陈 斌, 黄 备等. 夏季舟山渔场及邻近海域浮游动物群落结构特征分析. 动物学研究, 2010,31 (1): 99-107.

[39] Shannon CE, Weaver W, Blahut RE et al. The mathematical theory of communication. Urbana: University of Illinois Press, 1949.

[40] Pielou EC. Ecological diversity. New York: Wiley, 1975.

[41] Simpson EH. Measurement of diversity. Nature, 1949, 163: 688 .

[42] 朱为菊,王全喜. 滴水湖浮游植物群落结构特征及对其水质评价. 上海师范大学学报: 自然科学版, 2011, 40 (4): 405-410.

[43］龚雪平,郝媛媛,许莎莎等. 黑河流域水环境质量评价. 中国科技论文在线, 2012.05.11.

[44] Gaston KJ. Global patterns in biodiversity. Nature, 2000, 405 (6783) : 220-227.

[45] Arrhenius O. Species and area. Journal of Ecology, 1921, 9(1) : 95-99.

[46] Mittelbach GG, Steiner CF, Scheiner SM et al. What is the observed relationship between species richness and productivity? Ecology, 2001, 82(9) : 2381-2396.

[47] Allen AP, Brown JH, Gillooly JF. Global biodiversity, biochemical kinetics, and the energetic-equivalence rule. Science, 2002,297 (5586) : 1545-1548.

[48 ] Stomp M, Huisman J, Mittelbach GG et al. Large-scale biodiversity patterns in freshwater phytoplankton. Ecology, 2011, 92(11) : 2096-2107.

[49] Rohde K. Latitudinal gradients in species diversity : the search for the primary cause. Oikos, 1992, 65(3) : 514-527.

[50] Dixon LK, Vargo GA, Johansson JOR et al. Trends and explanatory variables for the major phytoplankton groups of two southwestern Florida estuaries, U. S. A. Journal of Sea Research, 2009, 61(1/2) : 95-102.

[51］马国红,杜兴华,段登选等. 盐碱地鱼池浮游植物与 $\mathrm{pH}$ 、总碱度、总硬度、含盐量的关系. 齐鲁渔业, 2001, 18 (5): 36-39.

[52] Bernhard AE, Peele ER. Nitrogen limitation of phytoplankton in a shallow embayment in northern Puget Sound. Estuaries and Coasts, 1997, 20(4) : 759-769.

[53] 赛 - 巴雅尔图,黄 瑾, 谢贵娟等. 新疆博斯腾湖浮游细菌丰度对富营养化及咸化的响应. 湖泊科学, 2011,23(6): 934-941.

[54] 陈江南,蒋晓辉,杨一松等. 黑河下游额济纳地区林草植被对调水的响应. 中国水土保持, 2007,7:17-20.

[55] 武发思,鄄金灼, 蔡泽平等. 大、小苏干湖浮游藻类的群落组成特点研究. 水生生物学报, 2009,33(2):264-270.

[56] Morais P, Chícharo MA, Barbosa A. Phytoplankton dynamics in a coastal saline lake (SE-Portugal). Acta Oecologica, 2003, 24(S1): S87-S96.

[57] 孟顺龙,陈家长,范立民等. 2007 年太湖五里湖浮游植物生态学特征. 湖泊科学, 2009,21(6) :845-854.

[58] Guo QH, Ma KM, Yang L et al. A comparative study of the impact of species composition on a freshwater phytoplankton community using two contrasting biotic indices. Ecological Indicators, 2010, 10(2) : 296-302.

[59] 高 远,慈海釒, 开树财等. 沂河 4 条支流浮游植物多样性季节动态与水质评价. 环境科学研究, 2009,22 (2): 176-180.

[60 ] 张光辉,申建梅,张翠云等. 甘肃西北部黑河流域中游地表径流和地下水补给变异特征. 地质通报,2006,25(1/2): 251-255.

[61 ] 贺建桥,宋高举,蒋 喜等. 2006 年黑河水系典型流域冰川融水径流与出山径流的关系. 中国沙漠, 2008,28 (6): 1186-1189.

[62] 王根绪, 陈国栋, 沈永平. 干旱区受水资源胁迫的下游绿洲动态变化趋势分析一一黑河流域额济纳绿洲为例. 应 用生态学报, 2002,13(5):564-568.

[63］谢宗平,李 莉,耿晓杰等. 用原生动物评价黑河张掖段水质. 中国环境监测, 2009,25(2) : 35-38.

[64] 谢宗平,马国泰. 张掖地区造纸厂废水灌溉区域微型生物调查研究. 中国环境监测, 2001,17(2):42-44. 